\title{
Christian Perception of Jewish Preaching in Early Christianity?
}

\author{
Annette von Stockhausen
}

\section{Introduction}

When I began my research on the topic, I was quite optimistic that there would be evidence of a "Christian perception of Jewish preaching". I thought that the attraction that Judaism had from the very beginnings for Christians - former Jews and former pagans alike - was at least partly due to the preaching in the synagogues. And I thought that therefore there should be some reflection of this fact in the masses of treatises, letters, sermons, exegetical works, etc. that were written by ancient Christian writers and that have come down to our days.

This - as it turned out - over-estimation of the role of the preaching in the synagogues was surely also caused by my own Protestant heritage, and by the importance of the sermon in this tradition.

After having looked through presumably relevant ancient Christian texts in Latin, Greek, and Syriac, originating from Spain in the west $^{1}$ to Persia in the east ${ }^{2}$, and from the New Testament to the Byzantine era, ${ }^{3}$ I'd now rather like to put a question mark after the title of my paper

1 I. e. the "Epistula Severi" on the conversion of the Jewish community on the island of Menorca, cf. E. D. Hunt, St. Stephen in Minorca: An Episode in Jewish-Christian Relations in the Early 5th Century A.D., in: JThS 33/1982, 106-123, and Scott Bradbury (Ed.), Severus of Minorca: Letter on the Conversion of the Jews (OECT), Oxford 1996.

2 I. e. Aphrahat's Demonstrations, cf. Jacob Neusner, Aphrahat and Judaism. The Christian-Jewish Argument in Fourth-Century Iran (StPB 19), Leiden 1971.

3 Cf. the texts mentioned and treated by Averil Cameron, Byzantines and the Jews: Some Recent Work on Early Byzantium, in: BMGS 20/1996, 249-274, Andreas Külzer, Disputationes graceae contra Iudaeos. Untersuchungen zur byzantinischen antijüdischen Dialogliteratur und ihrem Judenbild (ByA 18), Stuttgart/Leipzig 1999, Andrew Sharf, Byzantine Jewry from Justinian to the Fourth Crusade, London 1971, Andrew Sharf, Jews and Other Minorities in Byzantium, Jerusalem 1995, Gilbert Dagron, Judaïser, TMCB 11/1991, 359-380, and Gilbert Dagron/Vincent Déroche, Juifs et Chrétiens dans l'Orient du VIIème siècle, TMCB 11/1991, 17-273. 
and ask: Is there a "Christian Perception of Jewish Preaching in Early Christianity" at all?

And as I will show, the answer is almost entirely a negative one. ${ }^{4}$

But before I present the few texts that seem to be relevant and before I consider their meaning, it is necessary to settle two terminological and methodological issues:

(1) What kind of speech do we mean at all, if we use the term "preaching"? And what is the Sitz im Leben of this "preaching"?

(2) What kind of sources are at our disposal, and what can we therefore hope to learn from them?

\section{1 "Preaching"}

Because there are already extensive studies, it is not necessary to discuss this matter here in depth. ${ }^{5}$ In my following considerations I'd like, therefore, to understand "preaching" and sermons in the special sense of texts originally orally spoken during a religious service which comment in one form or another on Scripture: ${ }^{6}$ The Sitz im Leben of preaching is the service/prayer in the synagogue or in the church, and there is also a necessary connection between preaching and the reading of the Holy Writ during this service/prayer.

I'd like, therefore, to distinguish this kind of speech from lectures in the context of "school" on the one hand and from panegyrics

4 The, as far as I see, first evidence for Christian perception of Jewish preaching (at least in the Latin speaking world) is the $9^{\text {th }}$ century bishop Agobard of Lyon, who complains in his treatise "De insolentia Judaeorum" (written in 826/27 to the Emperor Louis the Pious) about the thriving Jews in general and especially that some Christians find the preaching of the Jews better than that of their own priests (L. Van Acker [Ed.], Agobardi Lugdunensis Opera Omnia, Opusculum XI [CChr.CM 52], Turnhout 1981, 191-195, here: 194,125f.): “... ad hoc peruenitur, ut dicant imperiti christiani melius eis praedicare Iudeos quam presbiteros nostros." "... it reaches the point that inexperienced Christians say that the Jews preach to them better than our priests."

5 See the discussion of the evidence by Alexandre Olivar, La Predicación cristiana antigua (BHer.FT 189), Barcelona 1991, 641-669.

6 Cf. the definitions made by Klaus Berger, Hellenistische Gattungen im Neuen Testament, in: ANRW II 25.2/1984, 1031-1432, here: 1363-1371, Maurice Sachot, Art. Homilie, in: RAC 16 (1994), 148-175, here: 148.170-172, Folker Siegert, Drei hellenistisch-jüdische Predigten. Ps.-Philon, "Über Jona“, "Über Jona“ (Fragment) und "Über Simson", vol. 2: Kommentar nebst Beobachtungen zur hellenistischen Vorgeschichte der Bibelhermeneutik (WUNT 61), Tübingen 1992, 3-12, and Folker Siegert, Homily and Panegyrical Sermon, in: Stanley E. Porter (Ed.), Handbook of Classical Rhetoric in the Hellenistic Period (330 B.C.-A.D. 400), Leiden 1997, 421443. 
( $\pi \alpha v \eta \gamma v \rho$ @oí) - even in the broader context of the service ${ }^{7}-$ on the other hand.

Although school or teaching and service or ritual/prayer are connected to each other (especially in Judaism), ${ }^{8}$ we have to distinguish between the two: teaching and preaching are two different kinds of speaking to a religious community that have both their own Sitz im Leben and place.

Before the $3^{\text {rd }}$ century this distinction seems not to have been made, as there is no "terminus technicus" at all used in our sources, but only

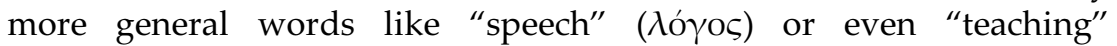

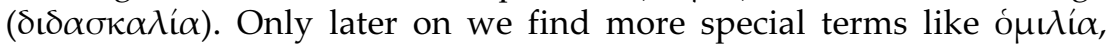
tractatus and sermo in connection with texts that are sermons in this strict sense. ${ }^{9}$

\subsection{What kind of sources do we have?}

A further problem, and the most vital one for our undertaking, is the question of which sources we can consult on our matter: what relevant sources do we have? And what kind of sources do we have?

\section{Excursus: Christian Preaching}

But before we look at possible Christian sources for Jewish preaching it seems to me reasonable to take a look at the sources for Christian preaching, ${ }^{10}$ because in view of that evidence the problem we are confronted with becomes all the more obvious.

7 Like homilies on the lives of martyrs or saints or orations on occasion of the consecration of a church. I would also count the pseudo-philonic "sermons" "De Jona" and "De Sampsone" among this genre and not look at them as sermons in the strict sense; but see Siegert, Drei hellenistisch-jüdische Predigten, vol. 2 (as in note 6), 7-9.

8 Cf. Hanswulf Bloedhorn/Gil Hüttenmeister, The synagogue, in: William Horbury/ William David Davies/John Sturdy (Eds.), The Cambridge History of Judaism, vol. 3: The Early Roman Period, Cambridge 1999, 267-297, here: 292-294, who point at the difference between praying (in the synagogue) and teaching (in the "Lehrhaus"), but who also state that synagogues were time and again used as places for teaching.

9 Cf. Olivar, Predicación cristiana (as in note 5), 487-514.

10 On Christian preaching generally cf. David G. Hunter (Ed.), Preaching in the Patristic Age. Studies in Honor of Walter J. Burghard, S.J., New York 1989, Sachot, Homilie (as in note 6), 155-175, and especially the comprehensive approach by Olivar, Predicación cristiana (as in note 5), but see also Jean Bernardi, La prédication des pères Cappadociens. Le prédicateur et son auditoire (Publications de la Faculté des 
Contrary to the findings regarding the Jewish evidence, there is an abundant amount of Christian sermons, filling many volumes of JeanPaul Migne's Patrologia latina and Patrologia graeca. Therefore we do know very well what Christian preaching - at least starting from the $2^{\text {nd }}$ half of the $2^{\text {nd }}$ century onwards ${ }^{11}$ - actually looked like: we know when, where and how often they preached; ${ }^{12}$ we can read the very words of these sermons; ${ }^{13}$ we know which exegetical and hermeneutical methods

Lettres et Sciences Humaines de l'Université de Montpellier 30), Paris 1968. The opinio communis on the origins of Christian preaching is that it is dependent of Jewish preaching (derashah), cf. for example Hans Martin Müller, Art. Homiletik, in: TRE 15 (1986), 526-565, here: 528; I have reservations about this, but cannot deal with this subject here.

11 Justin Martyr, 1 apol. 67 (on this text Gerard A. M. Rouwhorst, The Reading of Scripture in Early Christian Liturgy, in: Leonard Victor Rutgers [Ed.], What Athens has to do with Jerusalem. Essays on Classical, Jewish, and Early Christian Art and Archaeology in Honor of Gideon Foerster [Interdisciplinary studies in ancient culture and religion 1], Leuven 2002, 305-331, here: 323.326) is commonly reckoned the first clear evidence of Christian preaching after the reading of the Scriptures in

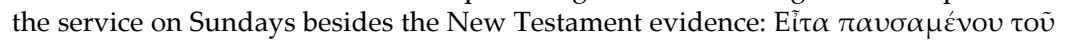

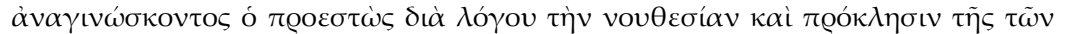

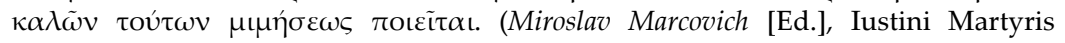
Apologiae pro Christianis [PTS 38], Berlin/New York 1994, 129,9-11) "Then, when the reader has ceased, the president verbally instructs, and exhorts to the imitation of these good things." (Alexander Roberts/James Donaldson/A. Cleveland Coxe, The Apostolic Fathers, Justin Martyr, Irenaeus [The Ante-Nicene Fathers 1], ND Grand Rapids [MI] 1989, 186) But it is not evident that this exhorting speech is connected

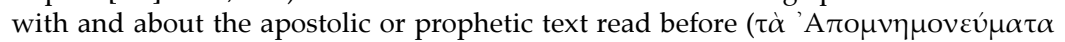

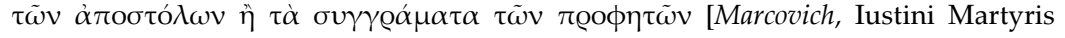
Apologiae pro Christianis, 129,8]).

But there are also extant texts like Melito's Passah-homily (an exegetical sermon on Ex. 12 cf. Mel., pass. 1 and 11 [Othmar Perler (Ed.), Méliton de Sardes, Sur la Pâque et fragments (SCh 123), Paris 1966, 60,3 and 66,72f.]) or the fragments of Valentinus Gnosticus transmitted by Clement of Alexandria (Val. Gn., fragm. 4 and 6 [Clem., str. IV 89,1-3 and VI 52,3-53,1]; cf. the commentary by Christoph Markschies, Valentinus Gnosticus? Untersuchungen zur valentinianischen Gnosis mit einem Kommentar zu den Fragmenten Valentins [WUNT 65], Tübingen 1992, 118152.186-204, especially 122-124). There are also 2 Clement (but see Wilhelm Pratscher, Der zweite Clemensbrief [KAV 3], Göttingen 2007, 25-27) and Clement of Alexandria's "Quis dives salvetur" to be mentioned, but I doubt whether they are speeches given during a service.

12 Cf. the short account by Hans Georg Thümmel, Materialien zum liturgischen Ort der Predigt in der Alten Kirche, in: Ekkehard Mühlenberg/Johannes van Oort (Eds.), Predigt in der Alten Kirche, Kampen 1994, 115-122.

13 There is a discussion about the relation between the actual delivered sermon and its literary form, i. e. between orality and literacy, which I can set aside here as irrelevant for the purpose of my study. 
the preachers used, which style, we even know how they reacted to disturbances by their audience. ${ }^{14}$

We have furthermore traces of a theoretical analysis of the "art of preaching": Augustine instructs the diacon Deogratias in Carthage on how to compose a catechesis in his "De cathechizandis rudibus"; $; 5$ and the fourth book of his "De doctrina christiana"16 could well be called a preacher's handbook. Augustine also tells us in his "Confessiones" how he perceived the preaching of Ambrosius. ${ }^{17} \mathrm{He}$ comments sometimes in his sermons on what he does when he preaches and how his audience reacts, as do Origen, John Chrysostom, and others. ${ }^{18}$

In stark contrast to these results obviously no ancient Christian author ever intended to write a treatise on Jewish worship in general or on Jewish preaching specifically. There is no extant tractatus de praedicatione Iudaeorum - and it is quite unlikely that we will ever discover a treatise like that.

Early Christian authors had no interest in this topic. And that is because they apparently saw no need to deal with it. I will return to this point later after having examined the evidence, when I will ask for the reasons for this lack of evidence.

14 On preacher and audience cf. Ramsay MacMullen, The preacher's audience (AD 350400), in: JThS 40/1989, 503-511; Marc Hirshman, The Preacher and his Public in Third-Century Palestine, in: JJS 42/1991, 108-114; Christoph Markschies, “... für die Gemeinde im Grossen und Ganzen nicht geeignet ..."? Erwägungen zu Absicht und Wirkung der Predigten des Origenes, in: ZThK 94/1997, 39-68; Philipp Rousseau, "The Preacher's Audience": A More Optimistic View, in: T. W. Hillard et al. (Eds.), Ancient History in a Modern University, vol. 2: Early Christianity, Late Antiquity and Beyond, Grand Rapids (MI)/Cambridge 1998, 391-400; Mary B. Cunningham/ Pauline Allen (Eds.), Preacher and Audience. Studies in Early Christian and Byzantine Homiletics (A New History of the Sermon 1), Leiden/Boston (MA)/Köln 1998; Wendy Mayer, John Chrysostom: Extraordinary Preacher, Ordinary Audience, in: Cunningham/Allen, Preacher and Audience, 105-137; Robert C. Hill, Reading the Old Testament in Antioch (Bible in Ancient Christianity 5), Leiden/Boston (MA) 2005, 184-186.

15 Edition: I. B. Bauer, De cathechizandis rudibus, in: Aurelii Augustini Opera XIII,2 (CChr.SL 46), Turnhout 1969, 115-178.

16 Edition: Joseph Martin, De doctrina christiana libri IV, in: Aurelii Augustini Opera IV,1 (CChr.SL 32), Turnhout 1962, here: 116-167; cf. M. Avilés Bartina, Predicación de san Agustín. La teoría de la retórica agustiniana y la práctica de sus sermones, in: Augustinus 28/1983, 391-417.

17 Aug., conf. V 13.23 (Lucas Verheijen [Ed.], Sancti Augustini Confessionum Libri XIII [CChr.SL 27], Turnhout 21990, 70); VI 4,6 (Verheijen, Confessiones, 77).

18 Cf. Olivar, Predicación cristiana (as in note 5), 774-878, and the literature mentioned in fn. 14. 
This gap is all the more important as early Christian writers otherwise did have great interest in topics related to Jews and Judaism and quite a lot of texts covering this field are in our hands. ${ }^{19}$

Many if not most of them are part of the early Christian literature adversus Judaeos. There are treatises and sermons, ${ }^{20}$ parts of antiheretical works and lives of saints, but also documents of synods and Church laws or texts in dialogue form. ${ }^{21}$

But if we look through all these writings we observe two things:

(1) They deal principally with theological themes, in the first place with the question of Jesus being the Messiah and later on with issues regarding the Trinity.

(2) They deal with Jewish religious practices for the most part only in regard to the keeping of the Sabbath and the festivals, to the observation of kashrut, and to circumcision. Prayer does not play an important part, ${ }^{22}$ only a minor theme in this regard is the birkat haminim as part of the prayers..$^{23}$

And more than a few of these texts are directed not to Jews at all and do also not reflect a Christian-Jewish discussion, but are part of the development of a Christian self-consciousness and are but one step towards formulating a Christian "orthodoxy".

Furthermore, and as has also already often been remarked, the controversy with Judaism was to a large extent a literary one, so that even if Jewish theological positions are mentioned, we often cannot decide whether these theological positions are not merely a literary frame for a dogmatic discussion based on exegesis of the biblical texts, especially based on the prophets' critique of the people for not keeping the precepts God had given to them.

To sum up: we have to keep in mind that we solely depend on sources that do not intend to give an answer to our question.

19 Cf. the texts treated by Heinz Schreckenberg, Die christlichen Adversus-Judaeos-Texte und ihr literarisches und historisches Umfeld (1.-11. Jh.) (EHS.T 172), Frankfurt/M. et al. ${ }^{4} 1999$ and the comprehensive "classic" studies by James William Parkes, The Conflict of the Church and the Synagogue. A Study in the Origins of Antisemitism, London 1934, and Marcel Simon, Verus Israel. Étude sur les relations entre chrétiens et Juifs dans l'Empire romain (135-425) (BEFAR 166), Paris 1948.

20 Cf. Bernard Blumenkranz, Die Judenpredigt Augustins. Ein Beitrag zur Geschichte der jüdisch-christlichen Beziehungen in den ersten Jahrhunderten, Basel 1946.

21 Cf. the literature treated in the works mentioned in note 19.

22 On Christian evidence of synagogue prayer in general cf. William Horbury, Jews and Christians in contact and controversy, Edinburgh 1998, 236-240.

23 On the problems in connection with the birkat ha-minim cf. now Steven T. Katz, The Rabbinic Response to Christianity, in: Idem (Ed.), The Cambridge History of Judaism, vol. 4: The Late Roman-Rabbinic Period, Cambridge 2006, 259-298, here: 280-294. 
Sometimes we have to read them even against the intention of their author - and sometimes there is nothing to read at all.

\section{What do we know about Jewish preaching in antiquity - apart from any supposed Christian evidence?}

Talking about Jewish preaching in antiquity seems to me like entering a minefield, as it is much disputed - and not at all as clear as it always seemed to be - what we definitely can say about it in historical perspective. ${ }^{24}$ I therefore shall only touch on the problems connected to our knowledge of Jewish preaching, but will give no answers. The following questions are crucial:

(1) What were "synagogues" like?25 Was there a religious "service" at all? Or was the synagogue more a room for common study and discussion - on religious topics as well as on political ones?26 And were there differences between Eretz Israel and the Diaspora, between Hebrew/Aramaic-speaking and Greek-speaking Judaism?27 What was the service in the synagogue like? ${ }^{28}$ Did it comprise prayer, reading of

24 Cf. the articles by G. Stemberger and F. Siegert in this volume and the literature mentioned in the following notes. Horbury, Jews and Christians in contact and controversy (as in note 22), 226, has rightly pointed to the general scarcity of evidence.

25 Cf. on the late evidence for synagogues Shaye J. D. Cohen, Pagan and Christian Evidence on the Ancient Synagogue, in: Lee I. Levine (Ed.), The Synagogue in Late Antiquity, Philadelphia 1987, 159-181; a more optimistic view with emphasis on the New Testament evidence can be found in Horbury, Jews and Christians in contact and controversy (as in note 22), 228-232. Also on the scholarship on synagogue service Rouwhorst, Reading of Scripture (as in note 11), 315-318.

26 Cf. Bloedhorn/Hüttenmeister, Synagogue (as in note 8), 268, Heather A. McKay, Sabbath and Synagogue. The Question of Sabbath Worship in Ancient Judaism (Religions in the Graeco-Roman World 122), Leiden et al. 1994, and Seth Schwartz, Imperialism and Jewish Society. 200 B.C.E. to 640 C.E (Jews, Christians, and Muslims from the ancient to the modern world), Princeton (NJ) 2001, 221-225, on the first century evidence.

27 Cf. Levine, Synagogue in Late Antiquity (as in note 25); Cohen, Pagan and Christian Evidence (as in note 25), 159-181; Avigdor Shinan, Sermons, Targums, and the Reading from Scriptures in the Ancient Synagogue, in: Levine (Ed.), Synagogue in Late Antiquity (as in note 25), 97-110; Schwartz, Imperialism and Jewish Society (as in note 26), 215-239.

28 Cf. the articles in the collections by Levine (Ed.), Synagogue in Late Antiquity (as in note 25), Steven Fine (Ed.), Sacred Realm. The Emergence of the Synagogue in the Ancient World, New York/Oxford 1996, Steven Fine (Ed.), Jews, Christians and Polytheists in the ancient synagogue: cultural interaction during the Greco-Roman period (Baltimore studies in the history of Judaism), London/New York 1999, and by Howard C. Kee/Lynn H. Cohick (Eds.), Evolution of the Synagogue. Problems and 
the Torah and the Prophets, the Targum or translation and a sermon about these readings? ${ }^{29}$ Did it comprise only one or two of these elements, but not all four? What is the relation of the Targum to the sermon? Was prayer or reading first? What is the role of the "piyyut"? 30

(2) Further questions relate to the sermon in particular: What was the sermon in Greek-speaking Judaism like? ${ }^{31}$ Are the petihtot we find in the midrashim really parts or reflections of actually held sermons? ${ }^{32}$

Progress, Harrisburg (PA) 1999, and the accounts of Stefan C. Reif, Judaism and Hebrew Prayer. New Perspectives on Jewish Liturgical History, Cambridge 1993, especially 53-87, and Bloedhorn/Hüttenmeister, Synagogue (as in note 8), especially 267-270 and 291f.; a summarizing account on the second temple period synagogues and on the later development of the synagogue is made by Peter Wick, Die urchristlichen Gottesdienste. Entstehung und Entwicklung im Rahmen der frühjüdischen Tempel-, Synagogen- und Hausfrömmigkeit (BZWANT 150), Stuttgart/Berlin/Köln 2002, 88-116.383-385. See also the discussion on how the synagogue is called and whether we can conclude from its naming as $\sigma v v \alpha \gamma \omega \gamma \eta$ or

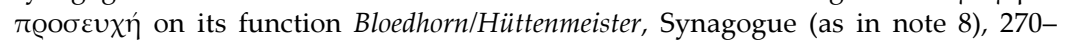
272, and Schwartz, Imperialism and Jewish Society (as in note 26), $216 \mathrm{f}$.

29 This seems to be the opinio communis since Leopold Zunz, Die gottesdienstlichen Vorträge der Juden historisch entwickelt. Ein Beitrag zur Alterthumskunde und biblischen Kritik, zur Literatur- und Religionsgeschichte, Berlin 1832, cf. Ismar Elbogen, Der jüdische Gottesdienst in seiner geschichtlichen Entwicklung. Dritte, verbesserte Auflage, Frankfurt/M. 1931, 194-198; Hermann L. Strack/Paul Billerbeck, Kommentar zum Neuen Testament aus Talmud und Midrasch. Vierter Band: Exkurse zu einzelnen Stellen des Neuen Testaments. Erster Teil, München 21956, 153-188, especially 171-188; Paul Billerbeck, Ein Synagogengottesdienst in Jesu

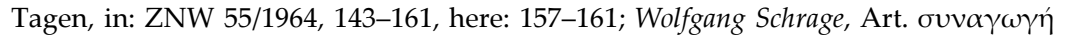
etc., in: ThWNT 7 (1964), 798-850; Emil Schürer/Geza Vermes/Fergus Millar/Matthew Black (Eds.), The History of the Jewish People in the Age of Jesus Christ (175 B.C.A.D. 135). A New English Version, vol. 2, Edinburgh 1979, 447-454, esp. 453; Joseph A. Fitzmyer, The Gospel According to Luke (I-IX) (AncB), Garden City (NY) ${ }^{21983,}$ 531; Sachot, Homilie (as in note 6), 149f. Reif, Judaism and Hebrew Prayer (as in note 28), 63f., at least puts it only as an assumption that there was a sermon in the synagogue.

30 Cf. Schwartz, Imperialism and Jewish Society (as in note 26), 263-274.

31 Cf. Hartwig Thyen, Der Stil der jüdisch-hellenistischen Homilie, Göttingen 1955, and Siegert, Homily and Panegyrical Sermon (as in note 6), 421-443; Folker Siegert, Drei hellenistisch-jüdische Predigten. Ps.-Philon, "Über Jona", "Über Simson" und "Über die Gottesbezeichnung 'wohltätig verzehrendes Feuer'“, vol. 1: Übersetzung aus dem Armenischen und sprachliche Erläuterungen (WUNT 20), Tübingen 1980; Siegert, Drei hellenistisch-jüdische Predigten, vol. 2 (as in note 6).

32 There is a broad consent that they are, cf. Joseph Heinemann, Art. Preaching. In the Talmudic Period, in: EJ 13 (1971), 994-998; Shinan, Sermons (as in note 27), 97-110; William-Richard Stegner, The ancient Jewish synagogue homily, in: David Edward Aune (Ed.), Greco-Roman literature and the New Testament. Selected Forms and Genres (SBibSt 21), Atlanta (GA) 1988, 51-69; but see the article by Günter Stemberger in this volume. 
Or are they rather a literary phenomenon? And what is the role of the rabbis in the synagogues? Did they preach in the synagogues? ? $^{33}$

The problem that evolves from these questions and their disputed answers for the subject of our study is that we have no clear picture in which we can embed the no less obscure and complex evidence by Christian authors.

\section{Supposed evidence of Christian knowledge of Jewish preaching}

Generally speaking the evidence for Jewish preaching in the first centuries CE is very sparse, both in Jewish and in Christian writings. And being so sparse, there is always the danger of finding evidence where there actually is none.

Therefore I will now deal with texts that have been referred to as evidence for Christian perception of Jewish preaching in the synagogues.

3.1 The alleged evidence of knowledge about Jewish preaching in Jerome's work

Our main source here is Jerome, monk and man of letters who lived and worked almost half of his life in Bethlehem at the turn of the $4^{\text {th }}$ to the $5^{\text {th }}$ century. He is the father of the church who is - besides Origen and to a lesser degree also Eusebius - most dealt with when it comes to the question of borrowing Jewish exegetical knowledge by Christian authors. ${ }^{34}$

33 Cf. Sachot, Homilie (as in note 6), 150-155, and Shaye J. D. Cohen, Were Pharisees and Rabbis the Leaders of Communal Prayer and Torah Study in Antiquity? The Evidence of the New Testament, Josephus, and the Early Church Fathers, in: Kee/Cohick, Evolution of the Synagogue (as in note 28), 89-105.

34 Cf. for example Benjamin Kedar-Kopfstein, Jewish Traditions in the Writings of Jerome, in: Derek R. G. Beattie/Martin J. McNamara (Eds.), The Aramaic Bible. Targums in their Historical Context (JSOT.S 166), Sheffield 1994, 420-430; Günter Stemberger, Exegetical Contacts between Christians and Jews in the Roman Empire, in: Magne Sæbø (Ed.), Hebrew Bible/Old Testament. The History of Its Interpretation, vol. 1: From the Beginnings to the Middle Ages (Until 1300). Part 1: Antiquity, Göttingen 1996, 569-586, here: 576-586, especially 581-583 on Jerome; Christoph Markschies, Hieronymus und die "Hebraica Veritas". Ein Beitrag zur Archäologie des protestantischen Schriftverständnisses?, in: Martin Hengel/Anna Maria Schwemer (Eds.), Die Septuaginta zwischen Judentum und Christentum (WUNT 72), Tübingen 1994, 131181; Schreckenberg, Christliche Adversus-Judaeos-Texte (as in note 19), 333-339; 
Samuel Krauss refers in his still much cited article "The Jews in the Works of the Church Fathers" 35 to some alleged remarks on Jewish preaching that Jerome ${ }^{36}$ makes on various occasions in his commentaries to the Old Testament, namely in his Commentaries on Isaiah (written between 408 and 410) and on Ezekiel (written between 410 and 414). ${ }^{37}$

I can be brief here because Günter Stemberger has - in his contribution to the Festschrift for Heinz Schreckenberg ${ }^{38}$ - already shown that Samuel Krauss took the texts out of their original context and has rather made them fit what he wanted to read rather than interpreted them in their proper meaning and context.

(1) Samuel Krauss cites a text from Jerome's commentary on Ezekiel and translates it as follows: "They say one to another: Come, let us listen to this or that Rabbi who expounds the divine law, with such marvellous eloquence; then they applaud and make a noise, and gesticulate with their hands." 39 The Latin text is: tales sunt usque hodie multi in ecclesiis, qui aiunt: "uenite audiamus illum et illum", mira eloquentia praedicationis suae uerba uoluentem, plausus que commouent et uociferantur et iactant manus. ${ }^{40}$

First of all Krauss does not translate "in ecclesiis" at all, which is crucial; secondly, there is no word "rabbi" in the Latin text.

If we look at the context of this section, it becomes clear that it is a commentary on Ezekiel 33.30-32:

Wolfram Kinzig, Jewish and "Judaising" Eschatologies in Jerome, in: Richard Kalmin (Ed.), Jewish Culture and Society under the Christian Roman Empire (Interdisciplinary studies in ancient culture and religion 3), Leuven 2003, 409-429.

35 Samuel Krauss, The Jews in the Works of the Church Fathers I-III, in: JQR 5/1892, 122-157; Idem, The Jews in the Works of the Church Fathers IV-V, in: JQR 6/1893, 82-99; Idem, The Jews in the Works of the Church Fathers VI, in: JQR 6/1894, 225261.

36 On Jerome's attitude to Judaism generally and the caution to be applied regarding his knowledge of Jewish traditions cf. Günter Stemberger, Hieronymus und die Juden seiner Zeit, in: Dietrich-Alex Koch/Hermann Lichtenberger (Eds.), Begegnungen zwischen Christentum und Judentum in Antike und Mittelalter. Festschrift für Heinz Schreckenberg (SIJD 1), Göttingen 1993, 347-364; Markschies, Hieronymus (as in note 34), 131-181; Hillel I. Newmann, Jerome's Judaizers, in: Journal of Early Christian Studies 9/2001, 421-452.

37 Krauss, Jews in the Works of the Church Fathers VI (as in note 35), 228.234-236. The argument of Krauss is for example repeated by Hirshman, Preacher and his Public (as in note 14), 111-113, cf. also Horbury, Jews and Christians in contact and controversy (as in note 22), 242.

38 Stemberger, Hieronymus (as in note 36), 361f.

39 Krauss, Jews in the Works of the Church Fathers VI (as in note 35), 234.

40 Franciscus Glorie (Ed.), S. Hieronymi Presbyteri opera. Pars I. Opera exegetica 4. Commentariorum in Hiezechielem Libri XIV (CChr.SL 75), Turnhout 1964, 479. 
Jerome comments on the verses Ez. 33.30-32 with an actualising comparison: Like the target group for the prophet in former times people nowadays go to the theatre to have a good time as they go to the church and hear a sermon to enjoy themselves; they do this for pleasure only, and never intend to act according to what they have heard.

There is no anti-Judaic undertone in this text; it is a critique which Jerome directs against his fellow-Christians. And there are many other texts, mostly in sermons, which confirm that "theatromania" was not uncommon with Christians in the time of the ancient Church. ${ }^{41}$

We therefore cannot conclude from this text, as Krauss has done, that there were famous preachers in the synagogues that attracted the Jews to come and hear them and that the people that heard their sermons showed their enthusiasm by applauding and cheering.

(2) In the commentary on Ezekiel, in book 11 on Ez. 34, Jerome states: qui cum populo persuaserint uera esse quae fingunt, et in theatralem modum plausus concitauerint, et clamores immemores fiunt imperitiae suae, et, adducto supercilio libratis que sermonibus atque trutinatis, magistrorum sibi assumunt auctoritatem. ${ }^{42}$ Krauss translates this once more in a way that fits his intended interpretation: "The Preachers make the people believe that the fictions which they invent are true; and after they have in theatrical fashion called forth applause [...] they arrogantly step forward, speak proudly and usurp the authority of rulers." He eventually explains this text with the following statement: "Jerome was an attentive observer; the Jewish preacher's theatrical manner is also mentioned by his contemporary, St John Chrysostom." ${ }^{43}$

But Jerome is not at all talking about Jewish preachers - as again Günter Stemberger has already observed ${ }^{44}$ - but about heretics and teachers in the church who teach not the right doctrine, as he states in the preceding sentence: quod et omnes quidem haeretici faciunt, ut carpant eloquia scripturarum, et quantum in se est maculent; sed ecclesiastici uiri qui dogmatum non custodiunt ueritatem, sed de suo corde confingunt magistram que habent praesumptionem suam, simili errore retinentur. ${ }^{45}$

More instructive for our question may be another text which Samuel Krauss cites. ${ }^{46}$ It is from book XVI of Jerome's commentaries on Isaiah, the explanation of Isa. 58.2: "Yet they seek me daily, and delight

41 Cf. for example John Chrysostom, Jud. IV 7.

42 Glorie, Commentariorum in Hiezechielem Libri XIV (as in note 40), 488.

43 Krauss, Jews in the Works of the Church Fathers VI (as in note 35), $234 \mathrm{f}$.

44 Stemberger, Hieronymus (as in note 36), 362.

45 Glorie, Commentariorum in Hiezechielem Libri XIV (as in note 40), $487 \mathrm{f}$.

46 Krauss, Jews in the Works of the Church Fathers VI (as in note 35), 235f. 
to know my ways: as a nation that did righteousness, and didn't forsake the ordinance of their God, they ask of me righteous judgments." Jerome comments on this verse with the following words: hoc proprie iudaeis conuenit, qui per singulos dies currunt ad synagogas, et in dei lege meditantur, scire cupientes quid abraham, isaac et iacob, quid ceteri sanctorum fecerint, et libros prophetarum ac moysi memoriter reuoluentes, decantant diuina mandata, quibus rectissime illud aptabitur: quaerent me mali, et non inuenient. sic enim scriptum est: omnis qui quaerit inuenit. ${ }^{47}$

In contrast to the last text we have here clearly a polemical, antiJudaic undertone: in this text Jerome does really speak about Jews and criticizes their way of religious life.

We learn from this commentary that Jerome at least seems to have knowledge of the following Jewish practices: Jews meet on certain days in the synagogue (per singulos dies currunt ad synagogas) and study the "Law of the Lord" (in dei lege meditantur). They want to know the deeds of the patriarchs and the other "saints" (scire cupientes quid abraham, isaac et iacob, quid ceteri sanctorum fecerint); they repeat from memory the books of the prophets and of Moses (libros prophetarum ac moysi memoriter reuoluentes) and they say over and over again the divine precepts (decantant diuina mandata).

Granted that Jerome's description - despite the pejorative tone - is reflecting Jewish customs of his time, we can discern only one part of Jewish religious practice as it was performed in the synagogue: the study of the Torah and of the prophets by heart. There is no mention of either prayers or reading of Torah and Haftarah, or of a sermon. As Jerome states that the Jews meet "per singulos dies", it seems reasonable to assume that he is not talking about the prayer on Sabbath but that he has something more like common learning in mind. either.

Therefore this text proves to be of no relevance for our question

\subsection{The New Testament evidence}

The evidence we find in the New Testament is different from that. ${ }^{48}$ But the New Testament itself is a very different kind of source in comparison to Jerome or the work of any other Christian writer. First

47 Marcus Adriaen (Ed.), S. Hieronymi presbyteri opera. Pars I. Opera exegetica 2A. Commentariorum in Esaiam libri XII-XVIII. In Esaia parvula adbreviatio (CChr.SL 73A), Turnhout 1963, 660.

48 The New Testament evidence plays a crucial part in almost all the studies on the early history of the synagogue and is often used in a quite uncritical way. Cf. the literature mentioned in fn. 28. 
and foremost because it is clearly to be placed before the "parting of the ways" of Judaism and the emerging Christianity.

It is therefore also a methodological question whether we can make use of the New Testament to obtain evidence of Jewish preaching at all. We have to ask whether the preaching Jesus and Paul in New Testament texts are an image of a Jewish preacher or rather the prototypes of the Christian?

There are quite a few passages in the New Testament that show us Jesus or one of the apostles preaching or - as I would rather put it teaching in the synagogue. ${ }^{49}$ But besides the quite stereotyped (and often very short) accounts in Matthew, Mark and John we find broader and more elaborate evidence in Luke and Acts. ${ }^{50}$ And I think we must pay special attention to this fact, because we have to judge whether the "sermons" Luke cites are transcripts of "real" sermons Jesus or Paul gave or whether they are rather part of his historiographical approach to the life of Jesus and the early history of the church in accordance with the rules of ancient Greek and Roman historiography. ${ }^{51}$

What can we learn then from Luke's portrayal?

The first text is Luke 4.16-21:52 Luke tells us something about prayer on the Sabbath in the synagogue. ${ }^{53}$ There is a reading from the scriptures, i. e. from the prophet Isaiah, ${ }^{54}$ and Jesus stands while he is performing this ritual reading (v. 16); he opens the book and reads from it (v. 17) and he shuts it again after having read, and returns it to the servant who gave it to him (v. 20) - and then at last he sits down and teaches the people in the synagogue.

49 Cf. (besides the texts mentioned in the following: Luke 4.16-21 and Acts 13.14-44)

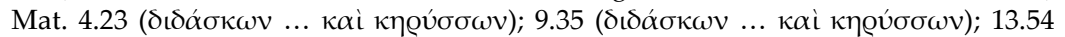

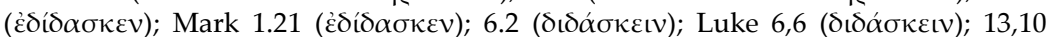

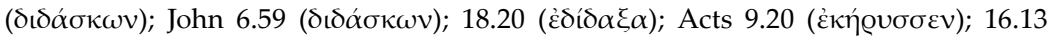

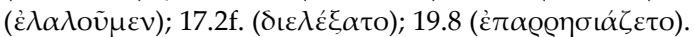

50 On Luke's attitude toward the synagogue cf. also Wick, Die urchristlichen Gottesdienste (as in note 28), 273-281.

51 On the historical value of the writings of Luke cf. Fitzmyer, Gospel According to Luke (as in note 29), 14-18.

52 Cf. the commentary on this text by Fitzmyer, Gospel According to Luke (as in note 29), 526-540.

53 Only Luke stresses that Jesus was frequenting the synagogue (Fitzmyer, Gospel According to Luke [as in note 29], 530) as later on the apostles and the early Christians frequently went to the temple (Acts $2.46 ; 3.1 ; 4.1 ; 5.12,42 ; 21.26$ ).

54 One should not infer from that that there was a haftarah already common in the synagogue of Jesus' time. The fact that Jesus is reading the verses of Isa. 61.1f. has more to do with what Luke as an author wants Jesus to show to us: Jesus reading a part of the Torah would not have helped Luke in his intention of showing the "proof from prophecy" that Jesus is the Messiah. 
We see that for Luke there is something like an exegetical sermon after the reading of the scriptures and that this sermon is performed sitting while the ritual reading is performed standing up. The scenario Luke presents us is more like the scenario of a teacher talking to his not-too-many pupils, at any rate it is not the scenario of an oration given before a huge crowd.

Can we regard this as a sermon? All the more as Jesus, according to Luke, only says one sentence? I have doubts.

In the second text, Acts 13.14-44, Luke presents us a different picture: ${ }^{55}$ Here the reading of the scriptures and exegesis are connected, too. Paul and Barnabas sit in the synagogue in Pisidian Antioch (v. 14) apparently they also sit during the reading of Law and Prophets (v. 15). After the readings the archisynagogues ${ }^{56}$ ask them to give a comforting

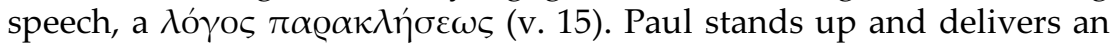
elaborate oration in the classical Greek manner (vv. 16-41).

After having left the synagogue Paul and Barnabas are asked to speak again on the following Sabbath (v. 42) and many of the Jews and the Godfearers follow them and urge them to stay (v. 43). On the following Sabbath in contrast to the beginning of the scene, not only the Jews, but almost the entire city come to hear the word of God (v. 44). The missionary plan of Paul and Barnabas to bring the word of God to Jews and pagans alike is accomplished.

Now, in contrary to the scene in Luke 4.16-21, Paul and Barnabas and probably the whole community are sitting while hearing the reading, and Paul is standing while he delivers his speech. Here we have the scenario of an ordinary public speech in the Hellenistic world, and also the style of the speech Paul is delivering points to that genre. ${ }^{57}$ So this text fits more to our notion of a sermon. But is it necessarily also a reflection of historical reality? I rather think that this "sermon" is caused by the genre Luke chose for his Acts of the Apostles: he writes a historical work, ${ }^{58}$ and one of the fundamental characteristics of ancient Hellenistic historiography is the composition of great speeches delivered by the protagonists at crucial points of the account. With this

55 Cf. the commentaries on this text by Joseph A. Fitzmyer, The Acts of the Apostles (AncB), New York et al. 1998, 505-524, and Charles K. Barrett, A Critical and Exegetical Commentary on the Acts of the Apostles, vol. 1: Preliminary Introduction and Commentary on Acts I-XIV (ICC 5), Edinburgh 1998, 620-661.

56 Cf. Bloedhorn/Hüttenmeister, Synagogue (as in note 8), 294f., on the office of archisynagogos.

57 Barrett, Acts of the Apostles I (as in note 55), 625; on the speeches in Acts cf. Fitzmyer, Acts of the Apostles (as in note 55), 103-108.

58 Cf. Berger, Hellenistische Gattungen (as in note 6), 1275-1277. 
speech (as well as with the other speeches in Acts) Luke complies with this rule of the genre.

\section{Excursus: Jews as listeners to Christian sermons}

While we have no evidence that there were Christians going to the synagogue in order to listen to a sermon, there is one text that gives evidence that Jews went to the church to listen to a Christian sermon but only to lead Christians afterwards, at the end of the liturgy, astray, as the author concludes in polemical tone. ${ }^{59}$

This text can be found in one of the homilies of Proclus, the $5^{\text {th }}$ century Archbishop of Constantinople, in Homily 2 "On the incarnation and On the Lampstand of Zechariah", § 9:60

"But I see that you are crowded together by force, and that it would be better at this point to finish my discourse. But if you are forcefully crowded together, remember that the kingdom of God belongs to those who take it by force. Permit me then to add but this: there may by chance to be a Jew in our midst, like the fox of Judah lurking in the vineyard of Christ. After the congregation is dismissed, he might stand outside and mock our words, saying such things as these: 'Why do you Christians invent such novelties and boast of things which cannot be proved? When did God ever appear on earth? Never, except in the time of Moses.'”

59 Cf. the commentary on this text by Jan H. Barkhuizen, Proclus of Constantinople: A Popular Preacher in Fifth-Century Constantinople, in: Cunningham/Allen, Preacher and audience (as in note 14), 179-200, here: 193-195.

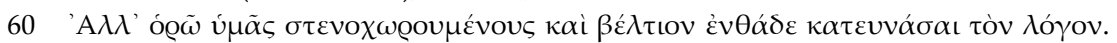

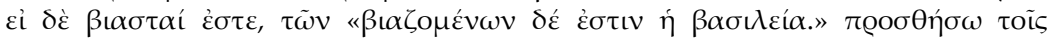

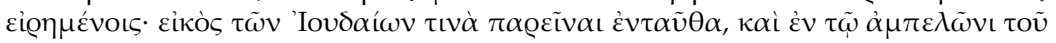

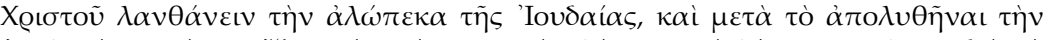

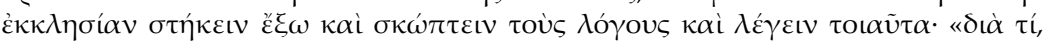

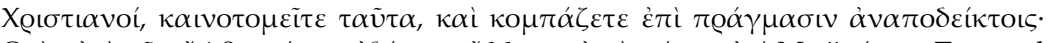

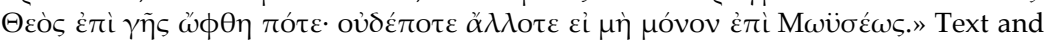
translation Nicholas Constas, Proclus of Constantinople and the Cult of the Virgin in Late Antiquity (SVigChr 66), Leiden/Boston (MA) 2003, 170-172. A further, similar text can be found in Homily 33 "On the apostle Thomas", \& 8 (François Joseph Leroy, L' homilétique de Proclus de Constantinople. Tradition manuscrite, inédits, études

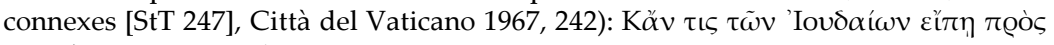

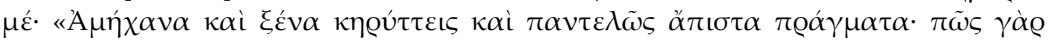

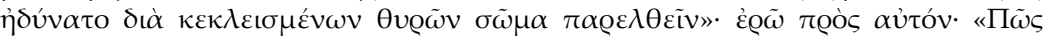

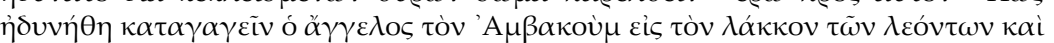

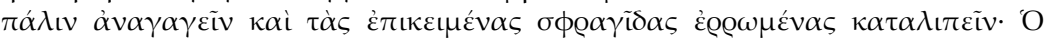

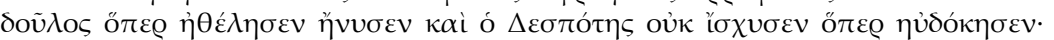

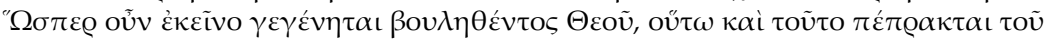

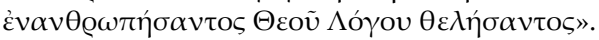


But here also we cannot discern clearly whether it is a real Jew Proclus is dealing with, and it seems more probable that it is not. But it certainly reflects the competition of Jews and Christians. ${ }^{61}$

\section{Reasons for the lack of evidence}

The answer to the question whether there is a Christian perception of Jewish preaching in Early Christianity is therefore a negative one.

But why is that? In a further step I will try to explain why early Christians tell us essentially nothing about Jewish preaching, especially while they do tell us a lot about Jews and Jewish life in general (of course - as we have already seen - highly mixed with polemics).

\subsection{What attracted Christians to Judaism?}

But what then attracted Christians to Judaism? From the second century onwards we hear again and again warnings that Christians should not "Judaize", ${ }^{62}$ that they should not live like Jews, ${ }^{63}$ that they should not adhere to Jewish customs, and above all that they should not go to the synagogues. ${ }^{64}$

61 On this topic see also Ambrose, ep. 74, especially $\S 10$ and 20 (Michaela Zelzer, Sancti Ambrosii Opera. Pars decima: Epistularum liber decimus. Epistulae extra collectionem. Gesta Concilii Aquileiensis [CSEL 82/3], Wien 1982, 54-73) on the affair of the burnt-down synagogue of Callinicum and above all John Chrysostom's Orations against the Jews.

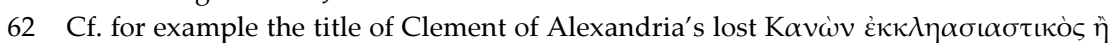

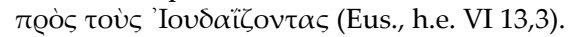

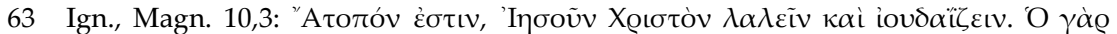

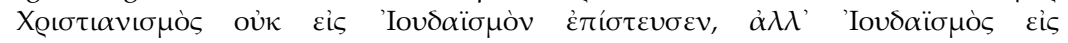

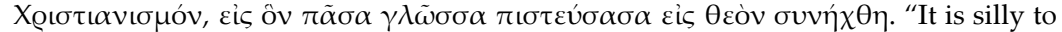
speak of Jesus Christ and to judaize. Christianity did not belief in Judaism, but Judaism in Christianity, to which every soul that believes in God is brought.";

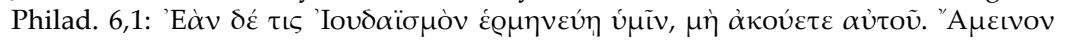

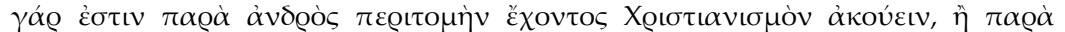

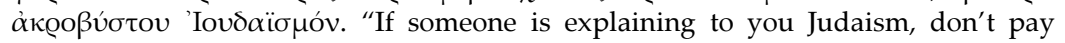
attention! It is better for a circumcised man to hear about Christianity than for a man not circumcised to hear about Judaism."

64 See for example Martyrium Pionii 13 (Herbert Musurillo, The Acts of the Christian

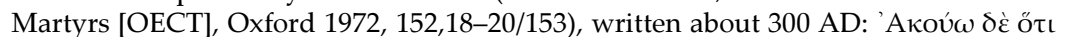

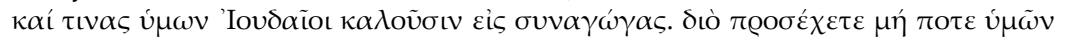

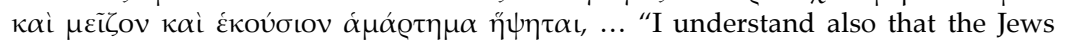
have been inviting some of you to their synagogues. Beware lest you fall into a greater, more deliberate sin ...". 
But what did Christians do there? What made the synagogue for Christians as attractive ${ }^{65}$ as the theatre, against which the fathers of the church polemicise again and again as it was obviously seen by them as a similar threat?

\section{Canones}

The best evidence for questions like that are found in the law of the Church, the canones, promulgated by synods from the $4^{\text {th }}$ century onwards, and in Church orders. ${ }^{66}$

The relevant - and, I think, well known - canons for the question on Judaising Christians are to be found in the canons of the Synod of Elvira in Spain, ${ }^{67}$ in the canons of the Synod of Laodicea, ${ }^{68}$ in the so called Apostolic Canons, ${ }^{69}$ and in the Church order of the so called Apostolic Constitutions, ${ }^{70}$ all dating to late $4^{\text {th }}$ century AD. Most of these canons are repeated again and again in later collections as well in the "orthodox", Chalcedonian and in the non-Chalcedonian "mono-" and "dyo-physite" churches.

If we look at what the canons prohibit, we can gather what Christians obviously did in connection with Judaism - and what they obviously did not, too: ${ }^{71}$

- Christians went into the synagogues. ${ }^{72}$

65 Cf. Steven Fine, Non-Jews in the synagogues of late-antique Palestine: Rabbinic and archeological evidence, in: Idem, Jews, Christians and Polytheists in the ancient synagogue (as in note 28), 224-242, here: esp. 231-236 on the rabbinic and archaeological evidence.

66 Cf. Bernhard Blumenkranz, Die jüdisch-christliche Missionskonkurrenz (3. bis 6 . Jahrhundert), in: Klio 39/1961, 227-233, here: 230f.; see also Charlotte Elisheva Fonrobert, Jewish Christians, Judaizers, and Christian Anti-Judaism, in: Virginia Burrus (Ed.), A People's History of Christianity, vol. 2: Late Ancient Christianity, Minneapolis 2005, 234-254, here: 243-250, on the Didascalia Apostolorum which cannot be further discussed here.

67 Cf. Pio de Luis, Art. Elvira, Council of, in: EECh 1/1992, 270, and Eckhard Reichert, Art. Elvira, Synode von, in: RGG 2 (1999), 1242 f.

68 Carlo Nardi, Art. Laodicea, Councils of, in: EECh 1 (1992), $472 \mathrm{f}$.

69 Cf. Bruno Steimer, Art. Apostolische Canones, LACL (1998), 46.

70 Cf. Marcel Metzger, Art. Konstitutionen, (Pseud-)Apostolische, TRE 19 (1990), 540544, and Bruno Steimer, Art. Apostolische Konstitutionen, LACL (1998), 46f.

71 See, for example, in this regard also Augustin's ep. 196 (CSEL 57, 216-230) to the catholic bishop Asellicus, the answer to his question on the relevance of Jewish customs in the church. Regarding Augustin's attitude to Judaism generally cf. Blumenkranz, Judenpredigt Augustins (as in note 20). 
- They prayed in the synagogue. ${ }^{73}$

- They brought with them oil into the synagogue and lit with it lamps. ${ }^{74}$

- They observed the Jewish ritual. ${ }^{75}$

- They asked Jews to bless their fruit. ${ }^{76}$

- They collected gifts from the Jews ${ }^{77}$ and especially unleavened bread. ${ }^{78}$

72 Const. App. II pinax 61 (Marcel Metzger [Ed.], Les Constitutions apostoliques. Tome

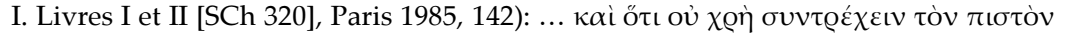

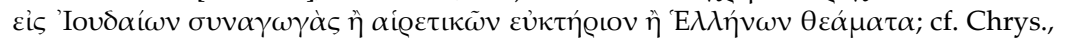

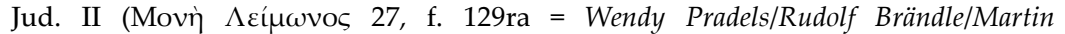
Heimgartner, Das bisher vermisste Textstück in Johannes Chrysostomus, Adversus

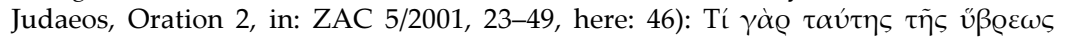

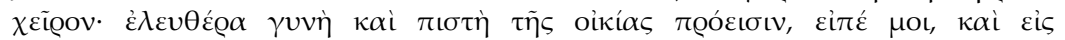

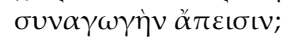

73 Can. App. 65 (Marcel Metzger [Ed.], Les Constitutions apostoliques. Tome III. Livre

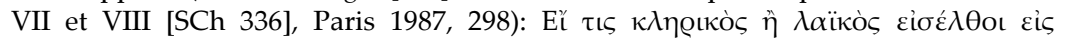

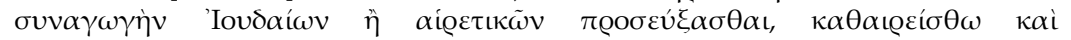
$\dot{\alpha} \phi о \varrho \iota \zeta \bar{c} \sigma \theta \omega$.

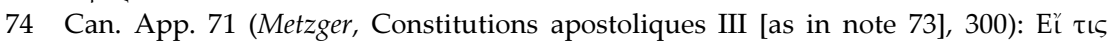

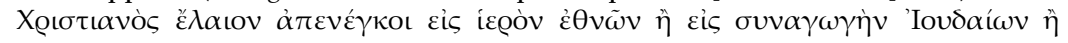
$\lambda u ́ x$ vous, $\alpha \dot{\phi} \phi o \varrho \iota \zeta \dot{\varepsilon} \sigma \theta \omega$.

75 Const. App. V pinax 12 (Marcel Metzger [Ed.], Les Constitutions apostoliques. Tome

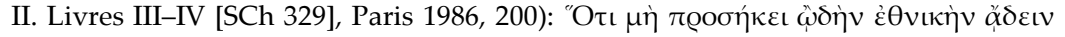

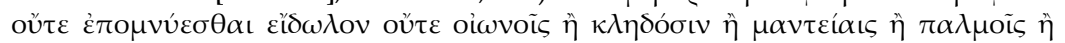

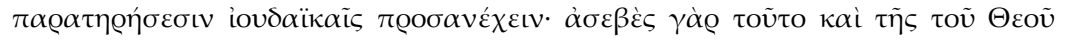

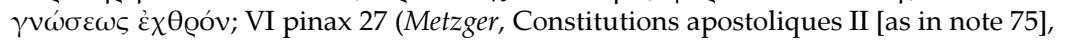

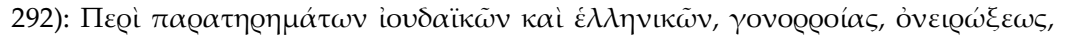

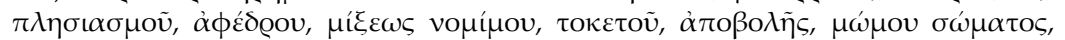

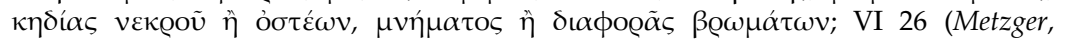

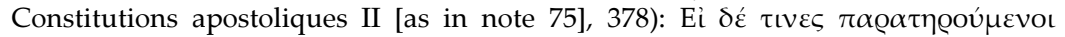

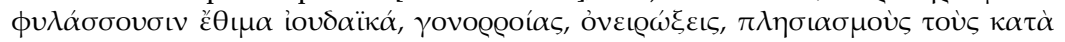

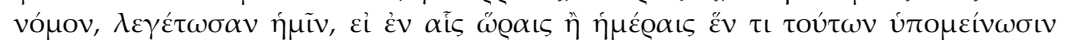

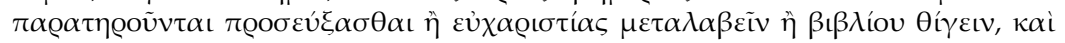

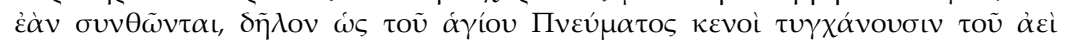

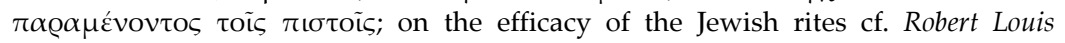
Wilken, John Chrysostom and the Jews. Rhetoric and Reality in the Late 4th Century, Berkeley (CA) 1983, 88-94.

76 Elvira Can. 49 (Friedrich Lauchert, Die Kanones der wichtigsten altkirchlichen Concilien nebst den apostolischen Kanones [SQS 12], ND Frankfurt/M. 1961, 21,1217): “De frugibus fidelium ne a Iudaeis benedicantur. Admoneri placuit possessores, ut non patiantur fructus suos, quos a Deo percipiunt cum gratiarum actione, a Iudaeis benedici, ne nostram irritam et informam faciant benedictionem: si quis post interdictum facere usurpaverit, penitus ab ecclesia abiciatur."

77 Laodicea Can. 37 (Lauchert, Kanones [as in note 76], 76,17-19): "O

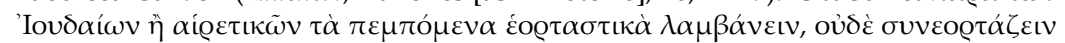

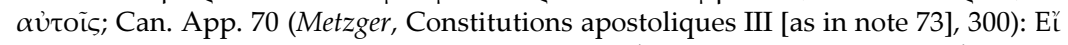

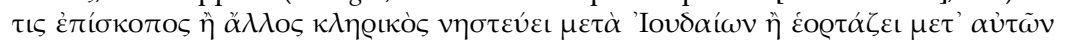

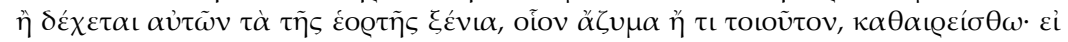

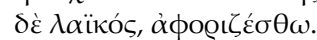


- They went to Jewish physicians. ${ }^{79}$

- They went to the Jewish Miqve. ${ }^{80}$

- They dined with Jews. ${ }^{81}$

- They celebrated together with the Jews, ${ }^{82}$ especially Passover. ${ }^{83}$

- They married Jewish women. ${ }^{84}$

- They rested together with the Jews on the Sabbath. ${ }^{85}$

- They fasted together with the Jews. ${ }^{86}$

It is to be noted that there is no mention of Christians listening to a sermon in the synagogue; this obviously posed no problem.

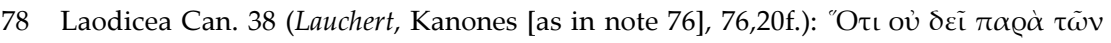

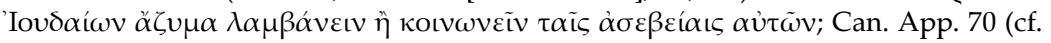
the preceding footnote); Quinisextum Can. 11 (Georges Neungatt/Silvano Agrestini, Concilium Trullanum 691-692, in: Guiseppe Alberigo et al. [Eds.], Conciliorum Oecumenicorum Generaliumque Decreta. Editio Critica. I. The Oecumenical Councils. From Nicea I to Niceas II (325-787) [CChr.COGD 1], Turnhout 2006, 203-

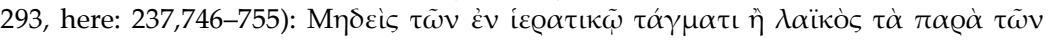

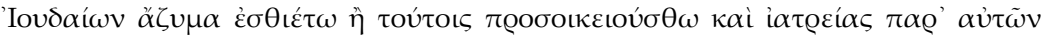

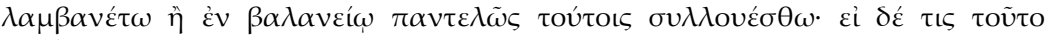

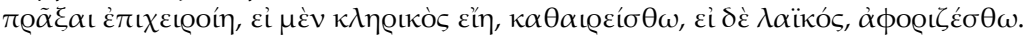

79 Quinisextum Can. 11 (cf. the preceding footnote).

80 Quinisextum Can. 11 (cf. fn. 78).

81 Elvira Can. 50 (Lauchert, Kanones [as in note 76], 21,18-21): “De Christianis qui cum Iudaeis vescuntur. Si vero quis clericus vel fidelis cum Iudaeis cibum sumpserit, placuit eum a communione abstineri, ut debeat emendari."

82 Const. App. V pinax 17 (Metzger, Constitutions apostoliques II [as in note 75], 200):

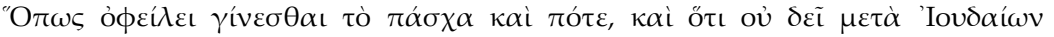

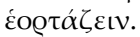

83 Can. App. 7 (Metzger, Constitutions apostoliques III [as in note 73], 276): Eí $\tau ا \varsigma$

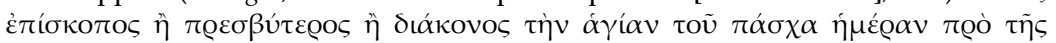

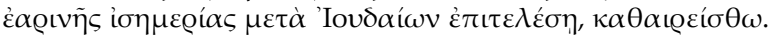

84 Elvira Can. 78 (Lauchert, Kanones [as in note 76], 25,29-26,2): “De fidelibus coniugatis si cum Iudaea vel gentili moechati fuerint. Si quis fidelis habens uxorem cum Iudaea vel gentili fuerit moechatus, a communione arceatur: quod si alius eum detexerit, post quinquennium acta legitima poenitentia poterit dominicae sociari communione."

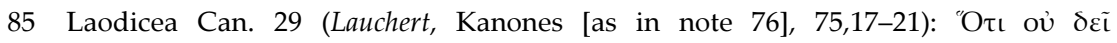

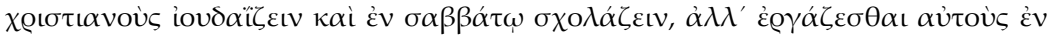

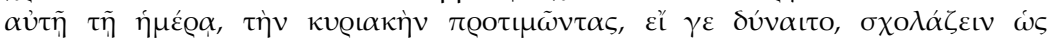

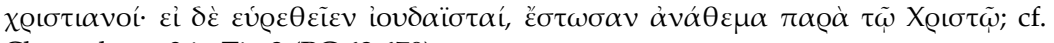
Chrys., hom. 3 in Tit. 2 (PG 62,679).

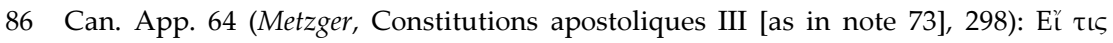

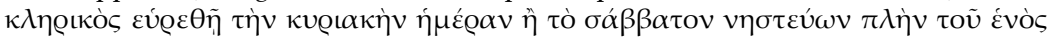

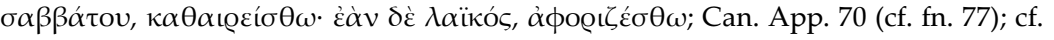
Chrys., Jud. III 1 (PG 48,857); hom. 3 in Tit. 2 (PG 62,679). 


\section{John Chrysostom}

To this impression can be added the evidence to be found in the notorious "Orations against the Jews" (or better "against Judaising Christians") by John Chrysostom, ${ }^{87}$ which can be dated to the autumn of 386 (Jud. I), to January (Jud. III) and to the autumn of 387 (Jud. IV, II, V-VIII) ${ }^{88}$

For example Chrysostom tells us that Christians went to the synagogue to swear an oath, because they thought that oaths sworn in the synagogue were more effective. ${ }^{89}$ Or. in Jud. I 5 and on various other occasions he remarks that Christians go to the synagogue to see and hear the trumpets. ${ }^{90}$

As we can see already in this small example, Chrysostom not only mentions Christian Judaising customs, but also gives us an explanation why they were so attracted to Jewish rituals and customs. It seems that to a great extent the attractiveness of Judaism was caused by the fact that the Jews kept festivals and customs that were described in the "Bible", but which were never or not any longer kept by the Church even though they were commanded in the Scriptures that were, after the exclusion of the Marcionites, regarded by Christians as "holy".

87 The literature on Chrysostom's Homilies on the Jews is abundant, cf. among others Marcel Simon, La pólemique antijuive de s. Jean Chrysostome et le mouvement judaïsant d'Antioche, in: AIPh 4/1936, 403-421; Adolf Martin Ritter, Erwägungen zum Antisemitismus in der Alten Kirche. Johannes Chrysostomus, "Acht Reden gegen die Juden", in: Bernd Moeller/Gerhard Ruhbach (Eds.), Bleibendes im Wandel der Kirchengeschichte, Tübingen 1973, 71-91; E. A. Grissom, Chrysostom and the Jews. Studies in Jewish-Christian relations in fourth-cent. Antioch, Ph.D. Southwest Baptist Theological Seminary Louisville (KY) 1978; Anne-Marie Malingrey, La controverse antijudaïque dans l'oeuvre de Jean Chrysostome d'après les discours Adversus-Judaeos, in: Valentin Nikiprowetzky (Ed.), De l'antijudaïsme antique à l'antisémitisme contemporain, Lille 1979, 87-104; Wilken, John Chrysostom and the Jews (as in note 75); Rudolf Brändle, Christen und Juden in Antiochien in den Jahren 386/87. Ein Beitrag zur Geschichte altkirchlicher Judenfeindschaft, in: Jud. 43/1987, 142-160; Adolf Martin Ritter, Chrysostomus und die Juden - neu überlegt, in: KuI 2/1990, 109-122; Rudolf Brändle/Verena Jegher-Bucher, Art. Johannes Chrysostomus I, in: RAC 18 (1998), 426-503; Mayer, Preacher and Audience (as in note 14), 105-137; Fonrobert, Jewish Christians (as in note 66), 236-243.

88 Wendy Pradels/Rudolf Brändle/Martin Heimgartner, The Sequence and Dating of the Series of John Chrysostom's Eighth Discourses Adversus Iudaeos, in: ZAC 6/2002, 90-116, table with dates and sequence of the orations in Pradels/Brändle/Heimgartner, Sequence and Dating (as in note 88), 106.

89 Chrys., Jud. I 3 (PG 48,847).

$90 \Sigma \alpha \dot{\alpha} \pi \iota \gamma \gamma \alpha \varsigma \theta \varepsilon \omega \varrho 0 \tilde{v} \nu \tau \alpha$ : He obviously refers to Rosh Hashana. Chrys., Jud. I 5 and 8 (PG 48,850 and 855f.); cf. II [Movì $\Lambda$ cí $\mu \omega v o \zeta 27$, f. 127vb-128va = Pradels/Brändle/Heimgartner, Textstück (as in note 72), 44-46] and IV 7 (PG 48,881). 
Christian writers did their very best to cope with the not-keeping of the Old Testament law by applying several hermeneutical techniques and doctrines, but at least the rank and file Christian obviously did not always conform to these teachings. ${ }^{91}$

Further points of attraction ${ }^{92}$ according to Chrysostom's account have been: Jews were regarded as wise men (Jud. III 3) and the Jewish teachers as more believable than the Christian ones (Jud. III 6). Jewish magic was believed as quite effective (Jud. I 6; VIII 5-7)..$^{93}$

I will take now two sections of the first oration against the Jews which focus on the matter of "holy books". ${ }^{94}$ As Chrysostom tells us,

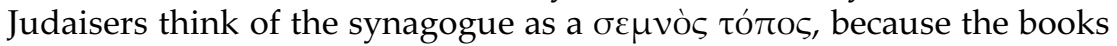
of the Law and the Prophets are kept in the synagogue. ${ }^{95}$ This is especially repulsive for Chrysostom because the Jews do not make the right use of these books - otherwise they would already have become Christians. Again, preaching is not mentioned. Chrysostom fears that the image of Christianity will be a negative one, if Christians go to the synagogue; especially weak Christians will be challenged whether Christianity is the right way at all ( $(5)$. For Chrysostom there is only right or wrong: if the Jewish customs and synagogues are holy, then the church must be wrong. The only exception to this rule is the Bible, because the Bible leads to salvation (§6).

The Christians had a problem: They relate to the Bible as a holy book - as do the Jews. But unlike them, they have it only in a translation and there were repeated controversies on the right wording of the text. Christians therefore always had a sense of inferiority vis-àvis the Jews.

This sense of inferiority is still obvious in a document as late as the second half of the $6^{\text {th }}$ century, in the famous "novella $146^{\text {" }}$ by

91 Cf. also the argument in Fonrobert, Jewish Christians (as in note 66), 234-254.

92 Cf. on the attraction of Judaism in general Wilken, John Chrysostom and the Jews (as in note 75), 66-94.

93 Cf. Wilken, John Chrysostom and the Jews (as in note 75), 83-88, and Giancarlo Lacerenza, Jewish Magicians and Christian Clients in Late Antiquity: The Testimony of Amulets and Inscriptions, in: Leonard V. Rutgers (Ed.), What Athens has to do with Jerusalem. Essays on Classical, Jewish, and Early Christian Art and Archeology in Honor of Gideon Foerster (Interdisciplinary Studies in Ancient Culture and Religion 1), Leuven 2002, 393-419.

94 Jud. I 5f. (PG 48,850-852). An English translation is to be found in Paul W. Harkins, Saint John Chrysostom. Discourses against Judaizing Christians (FaCh 68), Washington (DC) 1979, 18-24.

95 Cf. Wilken, John Chrysostom and the Jews (as in note 75), 79-83, and Horbury, Jews and Christians in contact and controversy (as in note 22), $234 \mathrm{f}$. 
Justinian. ${ }^{96}$ I subscribe to the view Leonard Rutgers pointed out some years ago: ${ }^{97}$ Justinian acts here not on the initiative of Jewish opponents regarding the use of Greek in the synagogues (as is stated in the preface). His law is rather an instrument of suppression: Jews should only use the Greek (or Latin) translation - or the Septuagint or Aquilas'

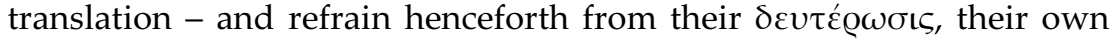
oral traditions. Thereby they will loose the advantage of having the "original" text, and will hopefully find their way to the true religion.

This is the most elaborate law we have on the Jewish religion, but again Jewish preaching is not seen as part of the Jewish threat to Christianity.

\subsection{The lack of evidence - one final reason}

I think I have sufficiently shown that there is no Christian perception of Jewish preaching in the first centuries CE. I have also reasoned what could have been the cause for this lack of perception.

Maybe there is one more reason for why there is no Christian perception of Jewish preaching: maybe the reason is that there was no such preaching in the synagogues in the late antique Roman Empire at all ${ }^{98}$ or that it at least was not as significant for Jewish worship as it was for the Christian. But that is a supposition I cannot prove.

96 The text (with a commentary) is to be found in Amnon Linder, The Jews in Roman Imperial Legislation, Detroit (MI)/Jerusalem 1987, 402-411, but see also Guiseppe

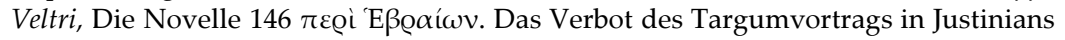
Politik, in: Martin Hengel/Anna Maria Schwemer (Eds.), Die Septuaginta zwischen Judentum und Christentum (WUNT 72), Tübingen 1994, 116-130. On laws regarding Jews in general cf. Linder, Jews in Roman Imperial Legislation (as in note 96), and Robert Louis Wilken, The Jews and Christian apologetics after Theodosius I Cunctos populos, in: HThR 73/1980, 451-471. On laws against Christian participating in synagogue service cf. also CTh XVI 8,1.

97 Leonard V. Rutgers, Justinian's Novella 146 Between Jews and Christians, in: Kalmin, Jewish Culture and Society (as in note 34), 385-407.

98 That does not imply that there was no teaching; but the "Sitz im Leben" of the teaching is different of that of preaching, cf. above I.1. 